\title{
Imaging findings in \\ encephalocraniocutaneous lipomatosis
}

\section{Figure Head CT and MRI}

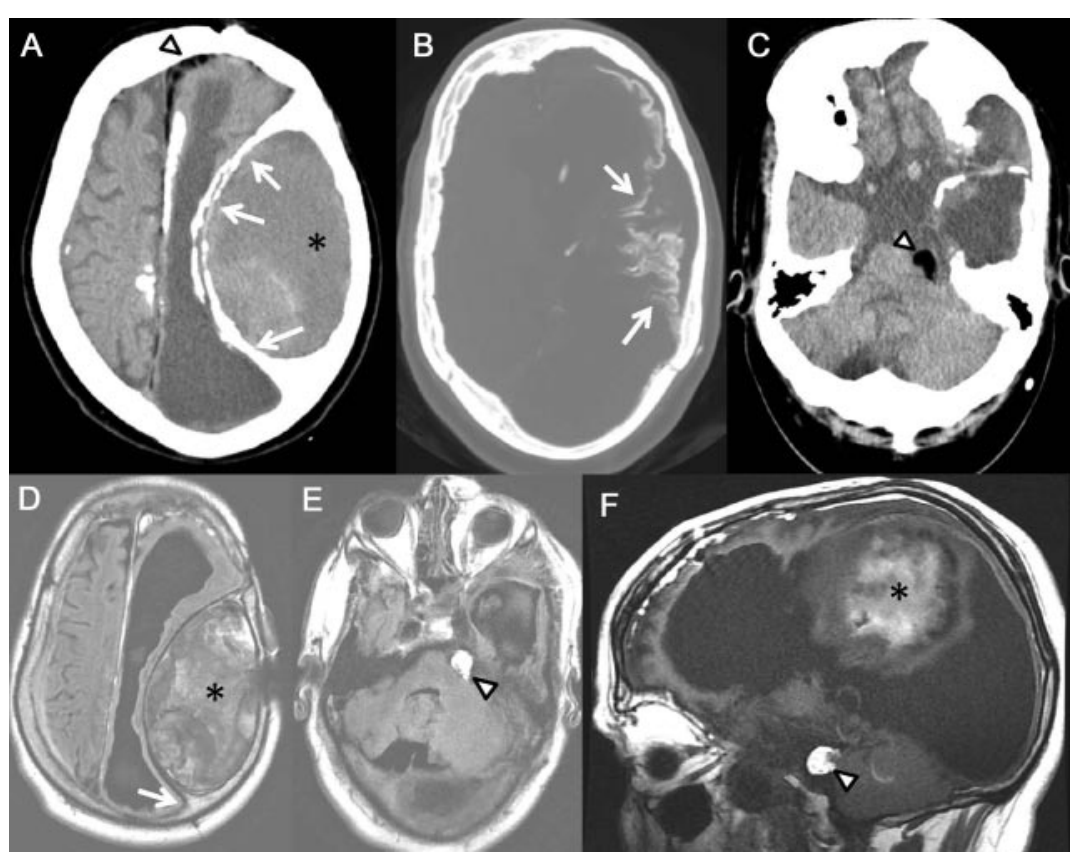

CT (A-C) and MRI (T2-fluid-attenuated inversion recovery [D, E], T1 [F]) show dilated left lateral ventricle and calcified cortex (B, arrows). Large heterogeneous epidural mass (asterisks; stable, likely fatty or proteinaceous material) has calcified margin continuous with calvarium ( $A, D$, arrows). Lipomas (arrowheads) appear along the interhemispheric fissure (A) and cerebellopontine angle (C, E, F).

A man in his 30s with encephalocraniocutaneous lipomatosis (ECCL), hydrocephalus, ventriculoperitoneal shunt, and Lennox-Gastaut syndrome was seen for epilepsy. He had multiple facial subcutaneous nodules (lipomas), near-blindness bilaterally, and right spastic hemiparesis. He was fluent, dysarthric, and followed one-step commands. A partially thrombosed internal carotid aneurysm was found on imaging (not shown).

ECCL is a neurocutaneous syndrome resulting from ectomesodermal dysgenesis, characterized by choristomas (ocular tumors), hairless scalp lesions (nevus psiloliparus), lipomas (facial, intracranial, particularly at the cerebellopontine angle, or intraspinal), and calcifications (figure). ${ }^{1}$ Half of patients have seizures, onethird have moderate mental retardation, and some have intracranial vascular malformations. ${ }^{2}$

Alexandra Svoronos, BA, Lawrence J. Hirsch, MD, Alexander G. Khandji, MD, New York, NY

Author contributions: A. Svoronos was the primary author of the manuscript. Dr. Hirsch was the treating physician of the patient, developed the study concept, and revised the manuscript. Dr. Khandji performed the analysis and interpretation of radiologic images and revised the manuscript.

Disclosure: A. Svoronos reports no disclosures. Dr. Hirsch serves/has served as a consultant for Lundbeck Inc., Upsher-Smith, and Ikano Therapeutics Inc.; has received speaker honoraria from GlaxoSmithKline, Pfizer Inc, Lundbeck Inc., and UCB; serves on the editorial board of the Journal of Clinical Neurophysiology and as contributing editor for Epilepsy Currents; receives publishing royalties from UpToDate and for Atlas of EEG in Critical Care (Wiley-Blackwell, 2010); has served on speakers' bureaus for GlaxoSmithKline, UCB, Pfizer Inc, and Lundbeck Inc.; and receives/has received research support from Eisai Inc., Pfizer Inc, Lundbeck Inc., UCB, Upsher-Smith, the American Epilepsy Society, and the Epilepsy Foundation. Dr. Khandji reports no disclosures.

Address correspondence and reprint requests to Dr. Lawrence J. Hirsch, Yale Comprehensive Epilepsy Center, Yale University School of Medicine, PO Box 208018, New Haven, CT 06520; lawrence.hirsch@yale.edu

1. Haberland C, Perou M. Encephalocraniocutaneous lipomatosis: a new example of ectomesodermal dysgenesis. Arch Neurol 1970;22:144-155.

2. Moog U. Encephalocraniocutaneous lipomatosis. J Med Genet 2009;46:721-729. 


\title{
Neurology
}

\author{
Imaging findings in encephalocraniocutaneous lipomatosis \\ Alexandra Svoronos, Lawrence J. Hirsch and Alexander G. Khandji \\ Neurology 2011;77;694 \\ DOI 10.1212/WNL.0b013e3182299fa9
}

\section{This information is current as of August 15, 2011}

\section{Updated Information \& Services}

\section{References}

Subspecialty Collections

Permissions \& Licensing

Reprints including high resolution figures, can be found at: http://n.neurology.org/content/77/7/694.full

This article cites 2 articles, 1 of which you can access for free at: http://n.neurology.org/content/77/7/694.full\#ref-list-1

This article, along with others on similar topics, appears in the following collection(s):

All Epilepsy/Seizures

http://n.neurology.org/cgi/collection/all_epilepsy_seizures

CT

http://n.neurology.org/cgi/collection/ct

MRI

http://n.neurology.org/cgi/collection/mri

Other neurocutaneous disorders

http://n.neurology.org/cgi/collection/other_neurocutaneous_disorders

Information about reproducing this article in parts (figures,tables) or in its entirety can be found online at:

http://www.neurology.org/about/about_the_journal\#permissions

Information about ordering reprints can be found online:

http://n.neurology.org/subscribers/advertise

Neurology ${ }^{\circledR}$ is the official journal of the American Academy of Neurology. Published continuously since 1951, it is now a weekly with 48 issues per year. Copyright Copyright (? 2011 by AAN Enterprises, Inc.. All rights reserved. Print ISSN: 0028-3878. Online ISSN: 1526-632X.

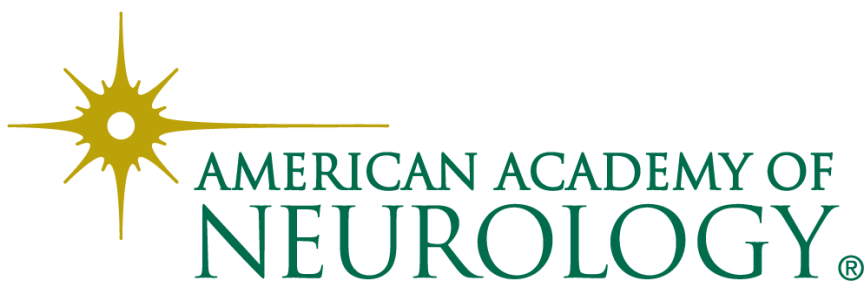

